Article

\title{
Assessment of Selected Baseline and Post-PCI Electrocardiographic Parameters as Predictors of Left Ventricular Systolic Dysfunction after a First ST-Segment Elevation Myocardial Infarction
}

\author{
Tomasz Fabiszak $^{1, * \mathbb{D}}$, Michał Kasprzak ${ }^{1} \mathbb{D}$, Marek Koziński $^{2} \mathbb{D}$ and Jacek Kubica ${ }^{1}$ \\ 1 Department of Cardiology and Internal Medicine, Collegium Medicum, Nicolaus Copernicus University, \\ ul. Skłodowskiej-Curie 9, 85-094 Bydgoszcz, Poland; medkas@o2.pl (M.K.); jwkubica@gmail.com (J.K.) \\ 2 Department of Cardiology and Internal Medicine, Medical University of Gdańsk, \\ ul. Powstania Styczniowego 9B, 81-519 Gdynia, Poland; marek.kozinski@gumed.edu.pl \\ * Correspondence: tfabiszak@wp.pl; Tel.: +48-52-585-40-23; Fax: +48-52-585-40-24
}

\section{check for} updates

Citation: Fabiszak, T.; Kasprzak, M.; Koziński, M.; Kubica, J. Assessment of Selected Baseline and Post-PCI Electrocardiographic Parameters as Predictors of Left Ventricular Systolic Dysfunction after a First ST-Segment Elevation Myocardial Infarction. J. Clin. Med. 2021, 10, 5445. https:// doi.org/10.3390/jcm10225445

Academic Editors: Michał Ciurzyński and Justyna Domienik-Karłowicz

Received: 22 October 2021

Accepted: 18 November 2021

Published: 22 November 2021

Publisher's Note: MDPI stays neutral with regard to jurisdictional claims in published maps and institutional affiliations.

Copyright: (c) 2021 by the authors. Licensee MDPI, Basel, Switzerland. This article is an open access article distributed under the terms and conditions of the Creative Commons Attribution (CC BY) license (https:/ / creativecommons.org/licenses/by/ $4.0 /)$.

\begin{abstract}
Objective: To assess the performance of ten electrocardiographic (ECG) parameters regarding the prediction of left ventricular systolic dysfunction (LVSD) after a first ST-segment-elevation myocardial infarction (STEMI). Methods: We analyzed 249 patients (74.7\% males) treated with primary percutaneous coronary intervention (PCI) included into a single-center cohort study. We sought associations between baseline and post-PCI ECG parameters and the presence of LVSD (defined as left ventricular ejection fraction $[\mathrm{LVEF}] \leq 40 \%$ on echocardiography) 6 months after STEMI. Results: Patients presenting with LVSD $(n=52)$ had significantly higher values of heart rate, number of leads with ST-segment elevation and pathological Q-waves, as well as total and maximal ST-segment elevation at baseline and directly after PCI compared with patients without LVSD. They also showed a significantly higher prevalence of anterior STEMI and considerably wider QRS complex after PCI, while QRS duration measurement at baseline showed no significant difference. Additionally, patients presenting with LVSD after 6 months showed markedly more severe ischemia on admission, as assessed with the Sclarovsky-Birnbaum ischemia score, smaller reciprocal ST-segment depression at baseline and less profound ST-segment resolution post PCI. In multivariate regression analysis adjusted for demographic, clinical, biochemical and angiographic variables, anterior location of STEMI (OR 17.78; 95\% CI 6.45-48.96; $p<0.001$ ), post-PCI QRS duration (OR 1.56; 95\% CI 1.22-2.00; $p<0.001)$ expressed per increments of $10 \mathrm{~ms}$ and impaired post-PCI flow in the infarct-related artery (IRA; TIMI 3 vs. $<3$; OR 0.14; 95\% CI 0.04-0.46; $p=0.001$ ) were identified as independent predictors of LVSD (Nagelkerke's pseudo $\mathrm{R}^{2}$ for the logistic regression model $=0.462$ ). Similarly, in multiple regression analysis, anterior location of STEMI, wider post-PCI QRS, higher baseline number of pathological Q-waves and a higher baseline Sclarovsky-Birnbaum ischemia score, together with impaired post-PCI flow in the IRA, higher values of body mass index and glucose concentration on admission were independently associated with lower values of LVEF at 6 months (corrected $\left.\mathrm{R}^{2}=0.448 ; p<0.00001\right)$. Conclusions: According to our study, baseline and post-PCI ECG parameters are of modest value for the prediction of LVSD occurrence 6 months after a first STEMI.
\end{abstract}

Keywords: myocardial infarction; ECG; risk stratification; left ventricular systolic dysfunction; primary PCI

\section{Introduction}

Electrocardiography (ECG), invented by Willem Einthoven nearly 120 years ago, remains one of the essential diagnostic modalities in cardiology [1], shaping the elementary division of acute coronary syndromes into those with and without persistent ST-segment depression, affecting the timing and mode of management and adding to short- and long-term risk stratification [2-4]. 
It is estimated that left ventricular systolic dysfunction (LVSD), recognized as a longterm consequence of myocardial infarction (MI), may affect up to $60 \%$ of post-MI patients [5]. Its occurrence mainly depends on the presence of frozen myocardium, size of post-MI necrosis, and occurrence of left ventricular remodeling [6,7].

Left ventricular ejection fraction (LVEF), measured with echocardiography, is by far the most popular method for diagnosing LVSD in the clinical setting [8].

LVSD is a well-recognized marker of unfavorable prognosis in post-MI patients [8], translating into a 3-4-fold increase in mortality and higher rates of cardiovascular adverse outcomes, such as cardiac rupture, sudden cardiac arrest, recurrent myocardial infarction, ventricular arrhythmias, stroke, prolonged hospitalization and rehospitalization [7,9-11]. The mortality rate among post-MI patients with asymptomatic LVSD after 12 months of MI is as high as $12 \%$ and amounts to $36 \%$ in symptomatic patients [12]. LVSD independently predicts short-, mid- and long-term mortality after MI [12-15].

There are many reports regarding the predictive value of ECG with respect to the development of LVSD after STEMI [4,16,17]. A vast part of these reports however, comes from the era of thrombolytic treatment of STEMI and was derived from non-uniform cohorts of patients regarding forms of MI, reperfusion treatment and pharmacotherapy. Nowadays, in consequence of current standards of STEMI management, incorporating percutaneous coronary intervention (PCI) as a means of effective and safe reperfusion, together with dual antiplatelet treatment, we have witnessed a spectacular reduction in the rates of death, reinfarction, heart failure and strokes.

Our investigation aims to assess the relationship between selected baseline and postPCI ECG variables and the presence of LVSD 6 months after a first STEMI.

\section{Methods}

\subsection{Study Design}

The investigation was a prospective cohort trial including patients receiving primary PCI with stent implantation for a first STEMI. Study design, including the inclusion and exclusion criteria, was described in detail in our previous publication exploring associations of ECG with post-MI left ventricular remodeling (LVR) [18]. Here, we provide only a brief overview of the study design. Major exclusion criteria were as follows: any previous myocardial infarction or coronary revascularization, presence of advanced acute or chronic heart failure (defined as class IV according to the Killip classification or class $\geq \mathrm{III}$ according to the New York Heart Association), presence of ECG abnormalities that might become study confounders (i.e., left bundle branch block, isolated posterior myocardial infarction, isolated right ventricular myocardial infarction, permanent atrial fibrillation), severe valvular heart disease, any cardiomyopathy, poorly controlled arterial hypertension (defined as blood pressure $\geq 180 / 110 \mathrm{mmHg}$ on hospital admission) and significant kidney dysfunction on hospital admission (defined as creatinine concentration exceeding $2 \mathrm{mg} / \mathrm{dL}$ ).

The analyzed ECG parameters included:

1. heart rate,

2. location of STEMI,

3. number of leads with ST-segment elevation,

4. sum of ST-segment elevation in all leads,

5. maximal ST-segment elevation in a single lead,

6. ST-segment resolution,

7. presence of reciprocal ST-segment depression $\geq 0.1 \mathrm{mV}$ on admission to hospital,

8. number of leads with pathological Q-waves [19],

9. Sclarovsky-Birnbaum ischemia score [2],

10. QRS complex duration.

The primary study endpoint was the occurrence of LVSD 6 months after STEMI. LVSD was defined as LVEF $\leq 40 \%$ on transthoracic echocardiography. This cut-off value was previously shown to be associated with unfavorable prognosis [10,20-24]. Additionally, LVEF $\leq 40 \%$ is used by the European Society of Cardiology guidelines for defining heart 
failure with reduced ejection fraction [25] and post-infarct patients who benefit from therapy with a beta-blocker, angiotensin-converting enzyme inhibitor or mineralocorticoid receptor antagonist [26].

First, we planned to compare the clinical, biochemical, angiographic and echocardiographic characteristics. We also assessed differences in ECG parameters between patients with and without LVSD 6 months after STEMI. Second, we prespecified uni- and multivariate analyses aimed at identifying predictors of post-infarct LVSD. A particular focus was placed on the investigated ECG parameters.

As a final step, we planned to check whether the variables predictive of the primary study endpoint were associated with lower values of LVEF (expressed as a continuous parameter) 6 months after STEMI.

Details of coronary angiography, PCI technique and ECG evaluation were also published in our previous publication [18]. Importantly, we aimed to restore normal blood flow in the infarct-related artery (IRA) during the primary PCI. Other non-culprit lesions of $\geq 90 \%$ in major coronary vessels were treated during the index hospitalization, while PCIs of the remaining significant stenoses (70-90\%) were done electively (within 1 month of STEMI occurrence).

Informed consent for participation in the study was obtained from each participant. The study received approval from the local Bioethics Committee of Collegium Medicum, Nicolaus Copernicus University in Torun (protocol code KB 440/2004). Throughout the entire course of the study, the Declaration of Helsinki and the principles of good clinical practice were applied.

\subsection{Echocardiographic Assessment}

Two-dimensional transthoracic echocardiography was performed in order to evaluate left ventricular systolic function using a Philips Sonos 7500 device (Philips, Andover, MA, USA) at two time points: before hospital discharge and after 6 months. Image acquisitions and measurements were performed according to the recommendations of the European Association of Echocardiography and the American Society of Echocardiography $[27,28]$. The biplane method of discs (modified Simpson's rule) based on apical 4-chamber and 2-chamber view was utilized for LVEF estimation. The echocardiographer was blinded to the ECG analysis. The intra-observer coefficient of variation for LVEF estimation for the first 50 patients was $2.5 \%$.

\subsection{Data Collection and Statistical Analysis}

Relevant data were collected and initially analyzed using Microsoft Excel spreadsheet software (Microsoft Corporation, Redmond, WA, USA). No missing data were present.

Descriptive analysis was used to summarize participant characteristics. Categorical data are presented as frequencies and percentages. Continuous variables are reported as medians and interquartile ranges. Correspondence with normal distribution was verified with the Shapiro-Wilk test. Between-group differences were tested using the Mann-Whitney $\mathrm{U}$ test for continuous variables and the Pearson Chi-square and Mantel-Haensztel tests for categorical variables. In order to identify predictors of LVSD at 6 months, logistic regression was used. The results are presented as odds ratios (OR) with $95 \%$ confidence intervals. Only variables with univariate $p$-values of $<0.1$ were included in the multivariate models. Stepwise backward selection was employed to select variables included in the best-fitting models. To identify predictors of LVEF at 6 months, we used multiple linear regression. Variables showing univariate $p$-values of $<0.1$ were considered eligible for multivariate analyses. The variables were then removed via stepwise backward selection. $p$-values of $<0.05$ were considered significant. Data analysis was conducted using Statistica version 13 (TIBCO Software Inc., Palo Alto, CA, USA) and SPSS version 23 (IBM, Armonk, NY, USA).

\section{Results}

\subsection{The Course of the Study}

The final analysis included 249 patients. A detailed description of the course of the study can be found in our previous publication [18]. 


\subsection{Clinical, Demographic, Angiographic and Biochemical Parameters}

The study cohort was primarily composed of middle-aged men. At baseline, patients who presented with LVSD after 6 months of follow-up showed a higher prevalence of diabetes mellitus, left anterior descending artery (LAD) as the IRA and TIMI 0 flow before PCI, but less frequent TIMI 3 flow post PCI. Slightly worse kidney function (assessed based on glomerular filtration rate), higher plasma glucose concentration on admission to hospital, larger enzymatic infarct size (as assessed with maximal concentration of troponin I and maximal activity of isoenzyme $\mathrm{MB}$ of creatinine kinase [CK-MB]), higher concentration of B-type natriuretic peptide (BNP) and more common usage of GPIIb/IIIa inhibitors during PCI could also be found in this group. Detailed characteristics of the study population are presented in Table 1.

Table 1. Clinical characteristics of the study population in relation to the occurrence of LVSD. Data are presented as median (lower quartile-upper quartile) or number (percent) when appropriate.

\begin{tabular}{|c|c|c|c|c|}
\hline Variable & $\begin{array}{c}\text { Overall Study } \\
\text { Population }(n=249)\end{array}$ & $\begin{array}{l}\text { Patients with LVSD } \\
\text { at } 6 \text { Months }(n=52)\end{array}$ & $\begin{array}{l}\text { Patients without LVSD } \\
\text { at } 6 \text { Months }(n=197)\end{array}$ & $p^{*}$ \\
\hline Age [years] & $57.0(51.0-64.0)$ & $61.0(52.0-67.0)$ & $56.0(51.0-64.0)$ & 0.090 \\
\hline Gender [male/female] & $186(74.7 \%) / 63(25.3 \%)$ & $42(80.8 \%) / 10(19.3 \%)$ & $144(73.1 \%) / 53(26.9 \%)$ & 0.258 \\
\hline Time from symptom onset to PCI [min] & $220.0(150.0-331.5)$ & $223.5(148.5-346.0)$ & $220.0(150.0-321.5)$ & 0.727 \\
\hline \multicolumn{5}{|c|}{ Risk factors for coronary artery disease } \\
\hline BMI $\left[\mathrm{kg} / \mathrm{m}^{2}\right]$ & $26.8(24.2-29.4)$ & $27.4(25.0-30.2)$ & $26.5(24.1-29.1)$ & 0.058 \\
\hline Hypertension & $103(41.4 \%)$ & $24(46.2 \%)$ & $79(40.1 \%)$ & 0.431 \\
\hline Diabetes mellitus & $50(20.1 \%)$ & $16(30.8 \%)$ & $34(17.3 \%)$ & 0.031 \\
\hline Current or ex-smoker & $164(65.9 \%)$ & $29(55.8 \%)$ & $135(68.5 \%)$ & 0.084 \\
\hline Positive family history of IHD & $61(24.5 \%)$ & $10(19.2 \%)$ & $51(25.9 \%)$ & 0.321 \\
\hline \multicolumn{5}{|c|}{ Angiographic characteristics } \\
\hline IRA: LAD/other & $121(48.6 \%) / 128(52.4)$ & $47(90.4 \%) / 5(9.6 \%)$ & $74(37.6 \%) / 123(62.4 \%)$ & $<0.001$ \\
\hline IRA TIMI 0 flow prior to PCI & $144(57.8 \%)$ & $39(75.0 \%)$ & $105(53.3 \%)$ & 0.005 \\
\hline IRA TIMI 3 flow post PCI & $229(92.0 \%)$ & $41(78.8 \%)$ & $188(95.4 \%)$ & 0.001 \\
\hline Multivessel coronary artery disease & $143(57,4 \%)$ & $34(65.4 \%)$ & $109(55.3 \%)$ & 0.192 \\
\hline Stent implantation & $245(98.4 \%)$ & $51(98.1 \%)$ & $194(98.5 \%)$ & 0.678 \\
\hline GP IIb/IIIa inhibitor usage & $66(26.5 \%)$ & $25(48.1 \%)$ & $41(21.0 \%)$ & $<0.001$ \\
\hline \multicolumn{5}{|c|}{ Biochemical characteristics } \\
\hline $\begin{array}{l}\text { eGFR (CKD-EPI equation) } \\
{\left[\mathrm{mL} / \mathrm{min} / 1.73 \mathrm{~m}^{2}\right]}\end{array}$ & $84.4(74.1-94.5)$ & $80.3(72.8-88.1)$ & $86.5(75.0-96.6)$ & 0.036 \\
\hline Glucose on admission [mg/dL] & $138.5(122.0-169.0)$ & $157.0(133.0-193.0)$ & $135(118.0-168.0)$ & 0.001 \\
\hline $\mathrm{cTnI}_{\max }[\mathrm{ng} / \mathrm{mL}]$ & $41.2(11.8-50.0)$ & $50.0(50.0-50.0)$ & $29.1(9.7-50.0)$ & $<0.001$ \\
\hline $\mathrm{CK}-\mathrm{MB}_{\max }[\mathrm{U} / \mathrm{L}]$ & $242.0(116.5-414.0)$ & $489.0(361.5-747.0)$ & $178.5(95.0-347.5)$ & $<0.001$ \\
\hline Total cholesterol [mg/dL] & $223.0(195.0-251.0)$ & $223.0(195.0-252.0)$ & $223.0(195.0-251.0)$ & 0.688 \\
\hline LDL-C [mg/dL] & $145.0(125.0-173.0)$ & $145.0(131.5-170.0)$ & $146.0(124.0-174.0)$ & 0.712 \\
\hline HDL-C [mg/dL] & $52.0(46.0-59.0)$ & $51.0(43.0-56.0)$ & $52.0(46.0-59.0)$ & 0.128 \\
\hline Triglycerides [mg/dL] & $82.0(59.0-128.0)$ & $89.5(62.5-130.5)$ & $78.0(58.0-125.0)$ & 0.103 \\
\hline BNP on admission $[\mathrm{pg} / \mathrm{mL}]$ & $53.9(27.9-106.5)$ & $74.8(31.8-155.7)$ & $50.6(27.3-101.9)$ & 0.045 \\
\hline BNP at discharge $[\mathrm{pg} / \mathrm{mL}]$ & $139.8(74.7-284.2)$ & 436.7 (223.6-735.5) & $111.9(65.3-198.3)$ & $<0.001$ \\
\hline
\end{tabular}

BMI, body mass index; BNP, B-type natriuretic peptide; CKD-EPI, Chronic Kidney Disease Epidemiology Collaboration; $\mathrm{CK}^{-M B} \mathrm{~B}_{\mathrm{max}}$ maximal activity of isoenzyme MB of creatinine kinase; $\mathrm{CTnI}_{\max }$, maximal activity of troponin I; eGFR, estimated glomerular filtration rate; HDL-C, high-density-lipoprotein cholesterol; IHD, ischemic heart disease; IRA, infarct-related artery; LAD, left anterior descending artery; LDL-C, low-density-lipoprotein cholesterol; LVSD, left ventricular systolic dysfunction; PCI, percutaneous coronary intervention; TIMI, thrombolysis in myocardial infarction score. ${ }^{*}$ for comparison between groups with and without LVSD at 6 months. 


\subsection{Echocardiographic Characteristics}

Table 2 presents major echocardiographic parameters at the time of discharge from hospital and after 6 months in the overall study population and in the subgroups with and without LVSD. Within 6 months of STEMI, a significant increase in median values of LVEF from $44 \%$ to $46 \%$ could be noted, leading to a decline in the percentage of patients with LVEF $\leq 40 \%$ from a baseline value of $33.7 \%$ to $20.9 \%$ after 6 months $(p<0.001$; Table 3 ).

Table 2. Echocardiographic characteristics of the study population in relation to LVSD occurrence. Data are presented as median (lower quartile-upper quartile).

\begin{tabular}{|c|c|c|c|c|}
\hline Variable & $\begin{array}{c}\text { Overall Study } \\
\text { Population }(n=249)\end{array}$ & $\begin{array}{l}\text { Patients with LVSD } \\
\text { at } 6 \text { Months }(n=52)\end{array}$ & $\begin{array}{l}\text { Patients without LVSD } \\
\text { at } 6 \text { Months }(n=197)\end{array}$ & $p^{*}$ \\
\hline \multicolumn{5}{|c|}{ At discharge } \\
\hline $\mathrm{LA}[\mathrm{mm}]$ & $40.0(37.0-43.0)$ & $41.0(38.0-45.0)$ & $39.0(37.0-42.0)$ & 0.007 \\
\hline LVEDd [mm] & $49.0(45.0-53.0)$ & $53.0(49.0-56.0)$ & $47.0(45.0-52.0)$ & $<0.001$ \\
\hline LVESd [mm] & $34.0(30.0-37.0)$ & $38.0(35.0-40.5)$ & $33.0(30.0-36.0)$ & $<0.001$ \\
\hline LVEDV [mL] & $99.4(84.0-121.0)$ & $121.5(102.5-132.5)$ & $93.0(81.0-111.0)$ & $<0.001$ \\
\hline LVESV [mL] & $55.0(45.0-69.0)$ & $75.0(66.0-84.5)$ & $51.0(42.5-62.0)$ & $<0.001$ \\
\hline LVEF [\%] & $44.0(39.0-48.4)$ & $36.0(33.5-38.5)$ & $45.9(42.0-50.0)$ & $<0.001$ \\
\hline LVSD (LVEF $\leq 40 \%)$ & $84.0(33.7 \%)$ & $45(86.5 \%)$ & $39(19.8 \%)$ & $<0.001$ \\
\hline WMSI [points] & $1.56(1.38-1.75)$ & $1.88(1.78-1.94)$ & $1.44(1.38-1.69)$ & $<0.001$ \\
\hline \multicolumn{5}{|c|}{6 months after discharge } \\
\hline $\mathrm{LA}[\mathrm{mm}]$ & $40.0(38.0-44.0)$ & $44.0(40.0-46.0)$ & $40.0(37.0-42.0)$ & $<0.001$ \\
\hline LVEDd [mm] & $50.0(46.0-54.0)$ & $55.0(52.0-57.0)$ & $48.0(45.0-53.0)$ & $<0.001$ \\
\hline LVESd [mm] & $34.0(31.0-37.0)$ & $40.0(36.0-44.0)$ & $33.0(31.0-36.0)$ & $<0.001$ \\
\hline LVEDV [mL] & $110.0(94.0-134.0)$ & $145.0(129.5-163.0)$ & $105.0(91.0-125.0)$ & $<0.001$ \\
\hline LVESV [mL] & $57.0(48.0-76.0)$ & $92.0(79.0-103.0)$ & $53.0(45.0-65.0)$ & $<0.001$ \\
\hline LVEF [\%] & $46.0(42.0-51.5)$ & $36.0(33.7-38.5)$ & $48.0(44.8-52.5)$ & $<0.001$ \\
\hline WMSI [points] & $1.44(1.31-1.69)$ & $1.88(1.75-1.94)$ & $1.38(1.31-1.50)$ & $<0.001$ \\
\hline
\end{tabular}

LA, left atrium end-systolic diameter; LVEDd, left ventricular end-diastolic diameter; LVEDV, left ventricular end-diastolic volume; LVEF, left ventricular ejection fraction; LVESd, left ventricular end-systolic diameter; LVESV, left ventricular end-systolic volume; LVSD, left ventricular systolic dysfunction; WMSI, wall motion score index. * for comparison between groups with and without LVSD at 6 months.

Table 3. Occurrence of LVEF $\leq 40 \%$ on transthoracic echocardiography at hospital discharge and at 6 months.

\begin{tabular}{cccc}
\hline & & \multicolumn{2}{c}{ LVEF $\leq 40 \%$ (LVSD) at $\mathbf{6}$ Months } \\
\cline { 2 - 4 } & & Absent $(\boldsymbol{n}=\mathbf{1 9 7})$ & Present $(\boldsymbol{n = 5 2})$ \\
\hline $\begin{array}{c}\text { LVEF } \leq 40 \% \text { at } \\
\text { hospital discharge }\end{array}$ & Absent $(n=165)$ & $158(63.5 \%)$ & $7(2.8 \%)$ \\
\cline { 2 - 4 } & Present $(n=84)$ & $39(15.7 \%)$ & $45(18.1 \%)$ \\
\hline
\end{tabular}

LVEF, left ventricular ejection fraction; LVSD, left ventricular systolic dysfunction.

Interestingly, patients with LVEF $\leq 40 \%$ at the time of discharge from hospital, but not 6 months after STEMI $(n=39)$, when compared with those presenting with LVEF $\leq 40 \%$ both at hospital discharge and LVSD 6 months after STEMI $(n=45)$, had a lower proportion of the LAD as the IRA (31 [79.5\%] vs. $42[93.3 \%] ; p=0.058)$, more frequent TIMI 3 flow in the IRA following PCI (38 [97.4\%] vs. 34 [75.6\%]; $p=0.002)$ and lower values of cardiac biomarkers, including maximal concentration of cardiac troponin I (50.0 [27.7-50.0] vs. 50.0 [50.0-50.0] ng/mL; $p=0.039$ ), maximal activity of CK-MB (354 [159-404] vs. 555 [378-761] U/L; $p<0.001)$ and BNP concentration on hospital discharge (177.3 [113.5-282.0] vs. 439.3 [233.0-751.5] pg/mL; $p<0.001)$. 


\subsection{Electrocardiographic Characteristics}

Detailed baseline and post-PCI electrocardiographic data are reported in Table 4.

Table 4. Electrocardiographic characteristics of the study population in relation to LVSD occurrence. Data are presented as median (lower quartile-upper quartile) or number (percent) when appropriate.

\begin{tabular}{|c|c|c|c|c|}
\hline Variable & $\begin{array}{c}\text { Overall Study } \\
\text { Population }(n=249)\end{array}$ & $\begin{array}{l}\text { Patients with LVSD } \\
\text { at } 6 \text { Months }(n=52)\end{array}$ & $\begin{array}{l}\text { Patients without LVSD } \\
\text { at } 6 \text { Months }(n=197)\end{array}$ & $p^{*}$ \\
\hline \multicolumn{5}{|c|}{ Baseline } \\
\hline Heart rate $[\mathrm{BPM}]$ & $75.0(62.0-88.0)$ & $81.0(68.5-97.0)$ & $74.0(60.0-85.0)$ & $<0.001$ \\
\hline Anterior location of STEMI & $116(47.0 \%)$ & $47(90.4 \%)$ & $69(35.0 \%)$ & $<0.001$ \\
\hline $\begin{array}{c}\text { Number of leads with ST-segment } \\
\text { elevation }[n]\end{array}$ & $4.0(3.0-6.0)$ & $6.0(5.0-7.0)$ & $3.0(3.0-5.0)$ & $<0.001$ \\
\hline Sum of ST-segment elevation [mm] & $8.5(4.0-14.0)$ & $13.8(9.8-18.0)$ & $7.0(4.0-12.0)$ & $<0.001$ \\
\hline Maximal ST-segment elevation [mm] & $3.0(2.0-4.0)$ & $3.5(3.0-5.0)$ & $2.5(1.5-4.0)$ & $<0.001$ \\
\hline $\begin{array}{l}\text { Number of leads with pathologic } Q \\
\text { waves }[n]\end{array}$ & $2.0(1.0-4.0)$ & $4.0(3.0-5.0)$ & $2.0(1.0-3.0)$ & $<0.001$ \\
\hline $\begin{array}{c}\text { Presence of reciprocal ST-segment } \\
\text { depression } \geq 1 \mathrm{~mm}\end{array}$ & $193(77.5 \%)$ & $34(65.4 \%)$ & $159(80.7 \%)$ & 0.019 \\
\hline QRS duration [ms] & $95.0(85.0-100.0)$ & $95.0(86.0-110.0)$ & $95.0(85.0-100.0)$ & 0.399 \\
\hline Sclarovsky-Birnbaum ischemia score & $\begin{array}{l}\text { grade 2: } 198(79.5 \%) \\
\text { grade 3: } 51(20.5 \%)\end{array}$ & $\begin{array}{l}\text { grade } 2: 35(67.3 \%) \\
\text { grade } 3: 17(32.7 \%)\end{array}$ & $\begin{array}{l}\text { grade 2: } 163(82.7 \%) \text {; } \\
\text { grade 3: } 34(17.3 \%)\end{array}$ & 0.014 \\
\hline \multicolumn{5}{|c|}{ Post PCI } \\
\hline Heart rate $[\mathrm{BPM}]$ & $77.0(66.0-89.0)$ & $83.0(72.0-94.0)$ & $75.0(64.0-88.0)$ & 0.003 \\
\hline ST-segment resolution [\%] & $60.6(30.0-88.9)$ & $39.4(0.0-69.3)$ & $70.0(40.0-100.0)$ & $<0.001$ \\
\hline ST-segment resolution $(\geq 50 \%)$ & $160(64.3 \%)$ & $22(42.3 \%)$ & $138(70.1 \%)$ & $<0.001$ \\
\hline $\begin{array}{l}\text { ST-segment resolution after PCI } \\
\text { (trichotomised) }\end{array}$ & $\begin{aligned} & <30 \%-62(24.9 \%) \\
\geq & 30-69 \%-82(32.9 \%) \\
\geq & 70 \%-105(42.2 \%)\end{aligned}$ & $\begin{aligned} & <30 \%-22(42.3 \%) \\
\geq & 30-69 \%-24(46.2 \%) \\
& \geq 70 \%-6(11.5 \%)\end{aligned}$ & $\begin{aligned} & <30 \%-40(20.3 \%) \\
\geq & 30-69 \%-58(29.4 \%) \\
\geq & 70 \%-99(50.3 \%)\end{aligned}$ & $<0.001$ \\
\hline $\begin{array}{c}\text { Number of leads with ST-segment } \\
\text { elevation }[n]\end{array}$ & $3.0(1.0-5.0)$ & $5.5(4.0-7.0)$ & $3.0(0.0-4.0)$ & $<0.001$ \\
\hline Sum of ST-segment elevation [mm] & $3.0(1.0-7.0)$ & $8.3(5.0-13.0)$ & $2.0(0.0-4.5)$ & $<0.001$ \\
\hline Maximal ST-segment elevation [mm] & $1.0(0.5-2.0)$ & $2.3(1.5-4.0)$ & $1.0(0.5-1.5)$ & $<0.001$ \\
\hline $\begin{array}{l}\text { Number of leads with pathologic } Q \\
\text { waves }[n]\end{array}$ & $3.0(2.0-5.0)$ & $5.0(4.0-7.0)$ & $3.0(1.0-4.0)$ & $<0.001$ \\
\hline QRS duration [ms] & $90.0(84.0-100.0)$ & $99.5(87.5-111.0)$ & $90.0(83.0-100.0)$ & 0.003 \\
\hline
\end{tabular}

BPM, beats per minute; LVSD, left ventricular systolic dysfunction; PCI, percutaneous coronary intervention; STEMI, ST-segment elevation myocardial infarction. * for comparison between groups with and without LVSD at 6 months.

\subsection{Characteristics Comparison of Patients with and without LVSD}

As reported in Table 1, both groups showed no significant demographic nor clinical differences, except for a higher prevalence of diabetes in the LVSD (+) group. LVSD (+) patients also presented a less favorable angiographic profile, including more frequent involvement of LAD as the IRA, more widespread usage of GP Ilb/IIIa inhibitor, a higher incidence of TIMI 0 and less frequent occurrence of TIMI 3 flow before and after PCI, respectively. Patients who presented with LVSD after 6 months were also characterized at baseline by worse renal function as assessed with glomerular filtration rate, higher blood glucose concentration on admission, more extensive release of myocardial necrosis markers and higher concentrations of B-type natriuretic peptide both on admission and at discharge. At discharge, both groups were receiving similar pharmacological treatment regarding aspirin, clopidogrel, statin, beta-blocker and ACEI/ARB (all used in $\geq 98.5 \%$ of patients); however, LVSD (+) patients were receiving aldosterone antagonist $(28.8 \%$ vs. $5.1 \% ; p<0.001)$ and diuretic $(28.8 \%$ vs. $4.6 \% ; p<0.001)$ more frequently than their LVSD $(-)$ counterparts. 


\subsection{Electrocardiographic Characteristics of Patients with LVSD}

The analyzed ECG parameters, both at baseline and post PCI, point to more severe ischemia and a more extensive MI in the LVSD (+) group. These include faster heart rate, more widespread ST-segment elevation and Q-wave development and higher total and maximal ST-segment elevation. More pronounced ischemia in LVSD (+) patients was also evidenced by a higher incidence of anterior wall location, reciprocal ST-segment depression $\geq 1 \mathrm{~mm}$ and grade 3 according to Sclarovsky-Birnbaum ischemia grading system at baseline. In post-PCI ECG assessment, lower incidence and degree of ST-segment resolution and longer duration of the QRS complex were associated with the presence of LVSD after 6 months. A detailed comparison of ECG parameters is reported in Table 4. As shown in Figure 1, we also found visual variability and a linear trend toward an increasing rate of LVSD at 6 months with an increasing duration of the QRS complex on admission (OR for the upper vs. combined lower and middle terciles 1.59; 95\% CI 0.80-3.17; $p=0.180$ ) and after PCI (OR for the upper vs. combined lower and middle terciles 3.42; 95\% CI 1.76-6.66; $p<0.001$ ). We also noticed significantly lower values of LVEF in the highest tercile of baseline and post-PCI QRS duration, compared with the lowest and middle terciles (see Figure 1).

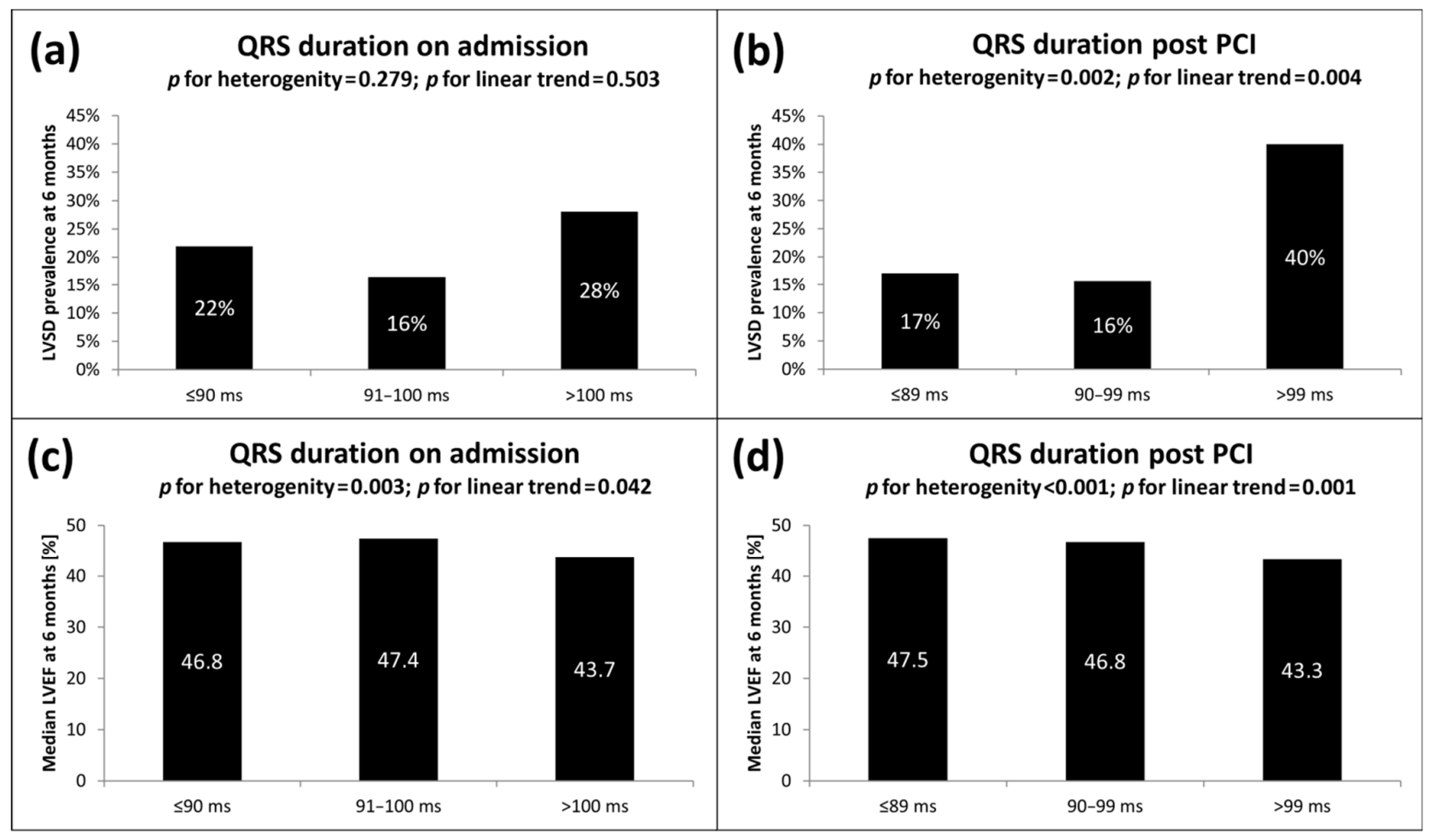

Figure 1. LVSD prevalence 6 months after STEMI according to terciles of QRS duration (a) on admission and (b) post PCI. Median LVEF 6 months after STEMI according to increasing terciles of QRS duration (c) on admission and (d) post PCI. LVEF, left ventricular ejection fraction; LVSD, left ventricular systolic dysfunction; ms, milliseconds; PCI, percutaneous coronary intervention; STEMI, ST-segment elevation myocardial infarction.

\subsection{Predictors of the Presence of LVSD 6 Months after Discharge from Hospital}

Initially, we performed a univariate regression analysis, including electrocardiographic parameters and the variables from Table 1, to identify possible predictors of LVSD after 6 months. Unadjusted models are summarized in Figure 2. Our results indicate strong association of LVSD after 6 months with the majority of electrocardiographic parameters assessed at the time of presentation to hospital and post PCI. Only baseline QRS duration did not show statistical significance. Of note, reciprocal ST-segment depression $\geq 1 \mathrm{~mm}$ at baseline pointed to a lower likelihood of LVSD after 6 months. 

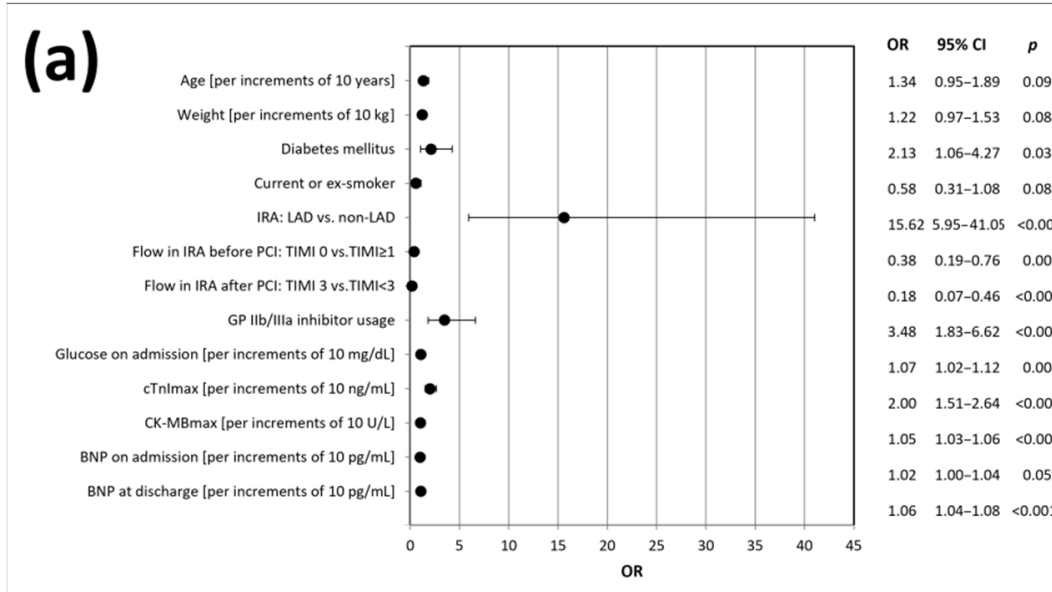

$\begin{array}{lll}1.34 & 0.95-1.89 & 0.091\end{array}$

$\begin{array}{lll}1.22 & 0.97-1.53 & 0.084\end{array}$

$\begin{array}{llll}2.13 & 1.06-4.27 & 0.033\end{array}$

$\begin{array}{llll}0.58 & 0.31-1.08 & 0.086\end{array}$

$\begin{array}{lll}15.62 & 5.95-41.05<0.001\end{array}$

$\begin{array}{lll}0.38 & 0.19-0.76 & 0.006\end{array}$

$\begin{array}{llll}0.18 & 0.07-0.46<0.001\end{array}$

$\begin{array}{llll}3.48 & 1.83-6.62<0.001\end{array}$

$\begin{array}{lll}1.07 & 1.02-1.12 & 0.004\end{array}$

$\begin{array}{llllll}2.00 & 1.51-2.64 & <0.001\end{array}$

$\begin{array}{llll}1.05 & 1.03-1.06 \quad<0.001\end{array}$

$\begin{array}{lll}1.02 & 1.00-1.04 & 0.059\end{array}$

$1.06 \quad 1.04-1.08<0.001$

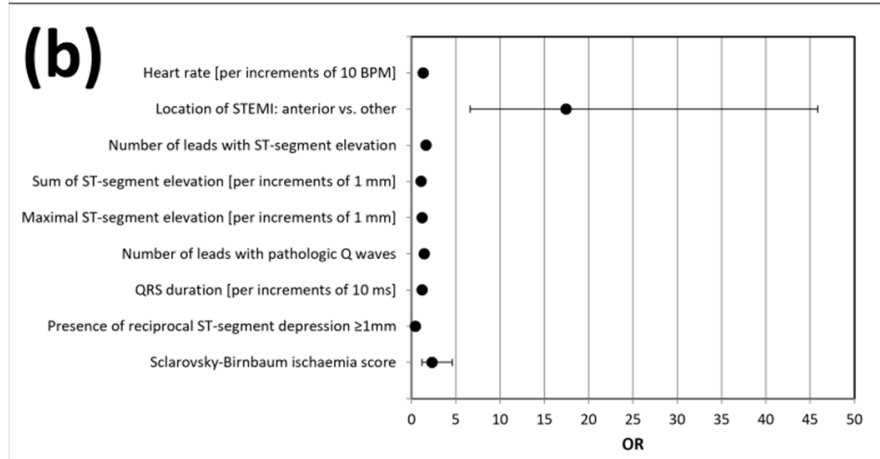

OR $\quad 95 \% \mathrm{Cl} \quad p$

$\begin{array}{lll}1.34 & 1.14-1.58 & <0.001\end{array}$

$\begin{array}{lll}17.44 & 6.63-45.88<0.001\end{array}$

$1.65 \quad 1.38-1.98<0.001$

$\begin{array}{lll}1.08 & 1.04-1.12 & <0.001\end{array}$

$\begin{array}{llll}1.20 & 1.05-1.37 & 0.006\end{array}$

$\begin{array}{lll}1.45 & 1.25-1.68 & <0.001\end{array}$

$\begin{array}{llll}1.20 & 1.00-1.46 & 0.055\end{array}$

$\begin{array}{lll}0.45 & 0.23-0.88 & 0.020\end{array}$

$\begin{array}{lll}2.33 & 1.17-4.63 & 0.016\end{array}$

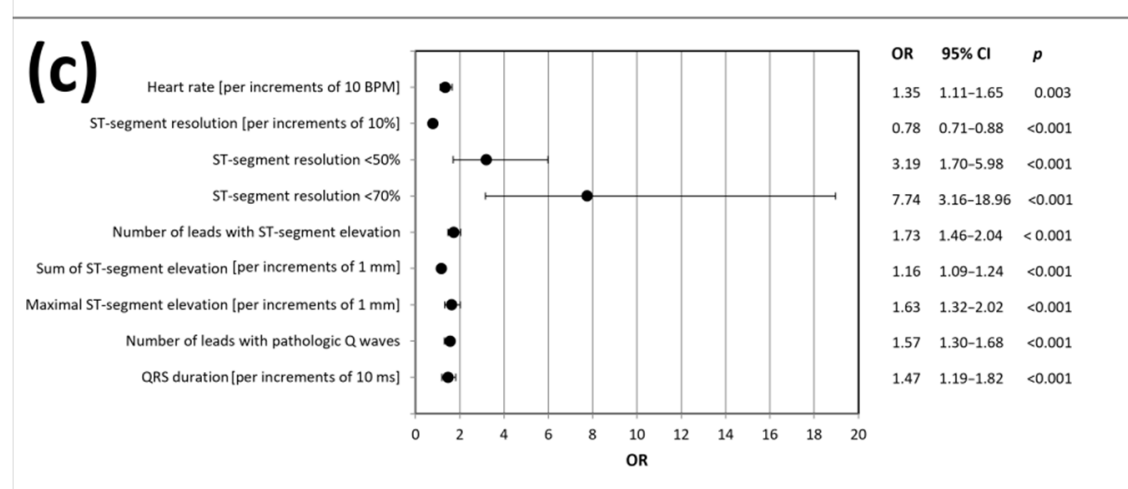

Figure 2. Predictors of LVSD occurrence after 6 months of follow-up according to the univariate logistic regression analysis: (a) demographic, clinical, angiographic and biochemical variables; (b) baseline electrocardiographic variables; (c) post-PCI electrocardiographic variables. BNP, B-type natriuretic peptide; CK-MBmax, maximal activity of isoenzyme MB of creatinine kinase; cTnImax, maximal concentration of troponin I; CI, confidence interval; IRA, infarct-related artery; LAD, left anterior descending artery; LVSD, left ventricular systolic dysfunction; ms, milliseconds; OR, odds ratio; $\mathrm{PCI}$, percutaneous coronary intervention; STEMI, ST-segment elevation myocardial infarction; TIMI, thrombolysis in myocardial infarction score.

Among the analyzed angiographic variables, LAD as the IRA and usage of GP IIb/IIIa inhibitor were identified as predictors of LVSD occurrence, while TIMI 0 flow before PCI and TIMI 3 flow post PCI were associated with a lower incidence of LVSD after 6 months. The biochemical variables predicting LVSD occurrence included glucose concentration on admission, maximal cardiac troponin I concentration and CK-MB activity, as well as BNP concentration at discharge from hospital. The only clinical variable predictive of LVSD was the presence of diabetes mellitus.

Next, in order to determine possible independent predictors of LVSD after 6 months, a multivariate logistic regression analysis was performed. We identified anterior location 
of STEMI, longer post-PCI QRS duration and impaired post-PCI flow in the IRA as the independent predictors of LVSD 6 months after STEMI (Figure 3).

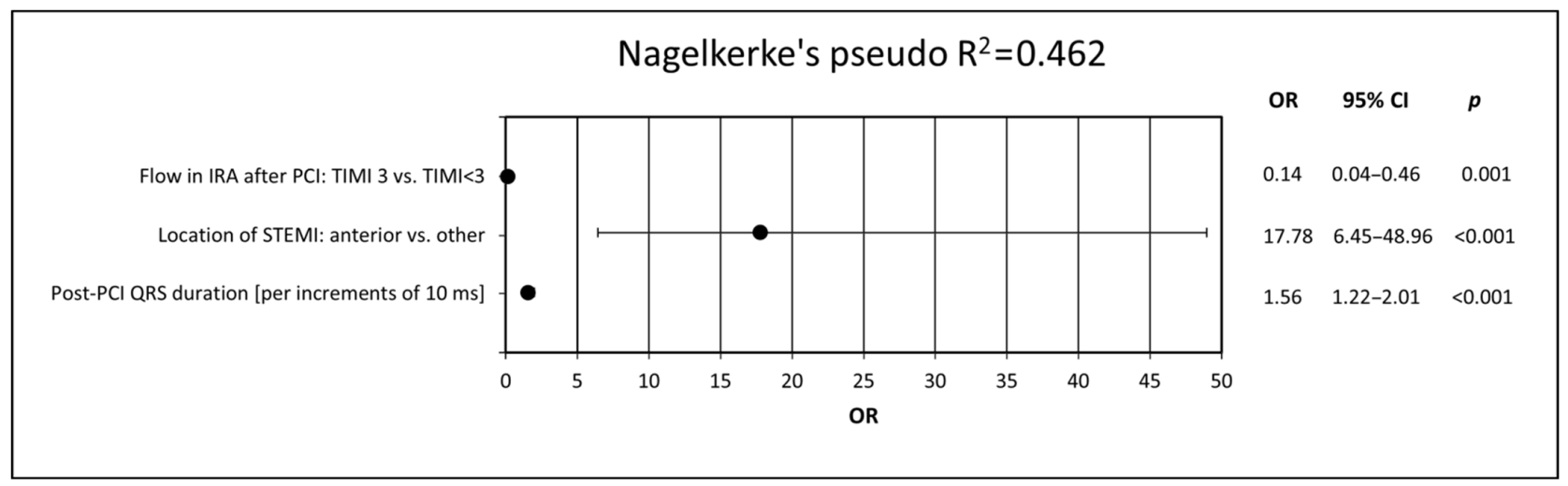

Figure 3. Predictors of LVSD presence after 6 months of follow-up. The model was created using multivariate logistic regression analysis by adding all electrocardiographic variables to the demographic, clinical, angiographic and biochemical data. CI, confidence interval; IRA, infarct-related artery; LVSD, left ventricular systolic dysfunction; ms, milliseconds; OR, odds ratio; PCI, percutaneous coronary intervention; STEMI, ST-segment elevation myocardial infarction, TIMI, thrombolysis in myocardial infarction score.

\subsection{Determinants of LVEF Deterioration}

In an attempt to more thoroughly explore the relationship between ECG parameters and LVEF, multiple linear regression analysis with a backward elimination was applied (Table 5). We found that anterior location of STEMI, longer post-PCI QRS duration, higher baseline number of pathological Q-waves and higher baseline Sclarovsky-Birnbaum ischemia score, together with impaired post-PCI flow in the IRA, higher values of body mass index and glucose concentration on admission, were independently associated with lower values of LVEF at 6 months.

Table 5. Impact of demographic, clinical, angiographic, biochemical and electrocardiographic variables on left ventricular ejection fraction (LVEF) 6 months after STEMI. The model was obtained using multiple regression by adding all electrocardiographic variables to the demographic, clinical and angiographic data.

\begin{tabular}{|c|c|c|c|c|c|}
\hline Variable & $\begin{array}{c}\text { Beta } \\
\text { Coefficient }\end{array}$ & $\begin{array}{l}\text { Beta Coefficient } \\
\text { Standard Error }\end{array}$ & $\begin{array}{c}\text { Direction } \\
\text { Component Beta }\end{array}$ & $\begin{array}{l}\text { Direction Component } \\
\text { Beta Standard Error }\end{array}$ & $p$ \\
\hline \multicolumn{6}{|c|}{ Model characteristics: $\mathrm{R}=0.682 ; \mathrm{R}^{2}=0.464 ;$ corrected $\mathrm{R}^{2}=0.448 ; p<0.00001$} \\
\hline Intercept & & & 70.49 & 3.71 & $<0.0001$ \\
\hline $\mathrm{BMI}\left[\mathrm{kg} / \mathrm{m}^{2}\right]$ & -0.10 & 0.05 & -0.20 & 0.10 & 0.0461 \\
\hline $\begin{array}{l}\text { Glucose on admission [per } \\
\text { increments of } 10 \mathrm{mg} / \mathrm{dL} \text { ] }\end{array}$ & -0.16 & 0.05 & -0.21 & 0.07 & 0.0021 \\
\hline IRA TIMI 3 flow after PCI & 0.12 & 0.05 & -3.20 & 1.36 & 0.0196 \\
\hline Anterior location of STEMI & -0.36 & 0.05 & -5.45 & 0.83 & $<0.0001$ \\
\hline $\begin{array}{l}\text { QRS duration on admission [per } \\
\text { increments of } 10 \mathrm{~ms} \text { ] }\end{array}$ & -0.28 & 0.05 & -1.36 & 0.25 & $<0.0001$ \\
\hline $\begin{array}{c}\text { Number of leads with pathologic } \\
\text { Q waves on admission }\end{array}$ & -0.24 & 0.05 & -0.82 & 0.18 & $<0.0001$ \\
\hline $\begin{array}{l}\text { Sclarovsky-Birnbaum ischemia } \\
\text { score [grade } 3 \text { vs. grade 2] }\end{array}$ & -0.12 & 0.05 & -2.33 & 0.94 & 0.0137 \\
\hline
\end{tabular}

BMI, body mass index; IRA, infarct-related artery; PCI, percutaneous coronary intervention; STEMI, ST-segment elevation myocardial infarction; TIMI, thrombolysis in myocardial infarction score. 


\section{Discussion}

\subsection{General Findings and Study Strengths}

According to our results, the majority of the analyzed electrocardiographic parameters measured at baseline and directly after PCI were associated with LVSD 6 months after STEMI. However, when we considered demographic, clinical, angiographic and biochemical characteristics of our study participants, among all assessed ECG parameters, only anterior location of STEMI and longer post-PCI QRS duration remained independent predictors of post-MI LVSD. Additionally, in our study, anterior location of STEMI, longer post-PCI QRS duration, higher baseline number of pathological Q-waves and higher baseline Sclarovsky-Birnbaum ischemia score, together with impaired post-PCI flow in the IRA, higher values of body mass index and glucose concentration on admission, were independently associated with lower LVEF at 6 months.

All electrocardiographic parameters selected for our analysis have been described in the literature to have some predictive value towards LVEF and LVSD. However, many of these reports come from the thrombolysis era and from inhomogeneous cohorts of patients. Our study cohort is characterized by homogeneity concerning the form of acute coronary syndrome presentation (exclusively patients with a first STEMI), reperfusion therapy (exclusively primary PCI) and subsequent pharmacotherapy [18]. This uniformity in study cohort profile, in conjunction with appropriate inclusion and exclusion criteria, allowed us to avoid many potential confounders and enables the extrapolation of these results to the majority of contemporary patients with a first STEMI. Importantly, besides multiple ECG parameters, we examined the impact of numerous demographic, clinical, angiographic and biochemical variables on LVSD occurrence.

\subsection{Heart Rate}

Increased heart rate is a well-recognized risk factor for all-cause and cardiovascular mortality in the general population [29-35], as well as in patients with stable coronary disease [36-40], heart failure [41-45] and MI [46-48]. In STEMI patients, heart rate $>70 \mathrm{bpm}$ recorded at hospital discharge was associated with 2-fold higher 1 year and 4 year mortality rates, while a $5 \mathrm{bpm}$ increment of heart rate was considered to enhance 1 year and 4 year mortality by $29 \%$ and $24 \%$, respectively [49]. As reflected by a U-shaped curve, extreme heart rate values (both high and low) are associated with increased mortality [50].

However, we have not found any relevant reports in the literature on the relation of heart rate in the early phase of STEMI with LVEF and the development of post-MI LVSD.

\subsection{STEMI Location}

Anterior wall location of STEMI is a strong independent predictor of bad prognosis, including death [51] and the occurrence of cardiogenic shock in the course of STEMI [52,53], even in the era of primary PCI for STEMI. Associations between anterior location of STEMI and more common development of LVSD [10,11] and left ventricular remodeling [54] have also been reported; however, they were not seen in all studies [55].

\subsection{ST-Segment-Elevation-Related Parameters}

We also evaluated three parameters related to ST-segment elevation (number of leads with ST-segment elevation, sum of ST-segment elevations in all leads, maximal ST-segment elevation in a single lead). According to Rodríguez-Palomares et al., the first two of the three parameters measured in pre-PCI ECG correlated with the size of myocardium at risk [56]. In research by Manes et al., the sum of ST-segment elevation, maximal ST-segment elevation and the number of leads with ST-segment elevation $\geq 1 \mathrm{~mm}$ in predischarge ECG in patients with anterior STEMI predicted a lower probability of recovery of left ventricular function after 90 days [17]. The 3 ST-segment-related parameters have been shown to predict post-STEMI mortality [50,57]. The amplitude of ST-segment elevation was found to be an independent predictor of post-MI 30-day mortality, particularly for total amplitudes $\geq 15 \mathrm{~mm}$ [58], and a marker of coronary microcirculation obstruction, performing 
even superior to ST-segment resolution [59]. It also predicted lack of improvement in left ventricular systolic function after STEMI in 6-month follow-up [60].

\subsection{ST-Segment Resolution}

Resolution of ST-segment elevation of $\geq 50 \%$ is considered a reliable indicator of patency of the IRA. However, restoration of myocardial tissue perfusion occurs only when complete $(\geq 70 \%)$ ST-elevation resolution is achieved. Complete $(\geq 70 \%)$ resolution of ST-segment elevation predicts lower 1-3 year mortality and lower rates of cardiovascular adverse events [61-63] and was associated with better preservation of left ventricular function in comparison with partial $(30-70 \%)$ or no $(<30 \%)$ ST-segment resolution. The beneficial outcome of early complete resolution of ST-segment elevation can be seen even after successful primary PCI, with early (i.e., directly after PCI) assessment being more precise in terms of predicting cardiovascular adverse events than assessment after 90 min [64-67]. Additionally, patients with such early ST-segment resolution also had higher LVEF in comparison to those who achieved ST-segment resolution after $90 \mathrm{~min}$ [64]. Failure to achieve complete ST-segment resolution also determined higher peak creatine kinase levels and more common prevalence of significant LVSD [68].

\subsection{Reciprocal ST-Segment Depression}

Besides ECG changes recorded in leads overlying the area of STEMI, the presence of reciprocal ST-segment depressions at baseline may also hold prognostic value. In literature reports it reflected larger infarct area and multivessel coronary artery disease and was associated with increased mortality and higher rates of heart failure, cardiogenic shock and second- and third-degree heart block in a manner proportional to their extent and amplitude [69,70]. Additionally, sustained ST-segment depressions after PCI are predictive of increased mortality after STEMI [71]. We have found no literature reports concerning associations of reciprocal ST-segment depressions with LVSD.

\subsection{Pathological Q-Waves}

The number of leads with pathological Q-waves is another well-recognized predictor of post-MI mortality. It successfully predicted lack of recovery of left ventricular systolic function (defined as absolute LVEF improvement by $<10 \%$ ) within 6 months after STEMI [60]. The presence of pathological Q-waves on the admission ECG is predictive of increased mortality, heart failure and cardiogenic shock after STEMI [3,4,72]. According to Lopez-Castillo et al., the sum of Q-wave depth at discharge performs better than the number of leads with pathological Q-waves as an independent predictor of LVSD development [73].

\subsection{Sclarovsky-Birnbaum Ischemia Score}

Based on the morphology of the terminal portion of the QRS complex and the relative magnitude of ST-segment elevation, the score identifies three grades of ischemia, with grade 3 reflecting most severe ischemia [74] and being an independent predictor of no-reflow phenomenon [67] and mortality [75,76]. Compared with grade 2, it indicates a more extensive infarction area and a higher rate of mortality, heart failure and reinfarction [67,76-84]. In terms of left ventricular systolic function, grade 3 of ischemia was associated with lower LVEF [82,85] and a higher incidence of LVSD [67].

\subsection{QRS Duration}

Prolonged QRS duration is another well-established predictor of increased mortality in STEMI patients [86-88]. The detrimental effects can already be seen with QRS duration of $\geq 100 \mathrm{~ms}$ [89]. An increase in 30-day mortality was even found for prolongation of QRS duration still within normal ranges (100 ms vs. $80 \mathrm{~ms})$ [50]. Literature reports documenting the relation between QRS duration and LVSD are much scarcer; however, 
they point to prolonged QRS duration, and even QRS duration of $\geq 100 \mathrm{~ms}$, as a predictor of LVSD $[16,90]$.

\subsection{Detailed Analysis of the Study Results}

As one can surmise from the above review of the prognostic value of the electrocardiographic parameters, the majority of the literature concerns their association with mortality, while there is a scarcity of data concerning associations with LVSD or LVEF. This fact precludes direct comparison of our results with the cited investigations. However, recognizing LVSD as a surrogate for cardiovascular mortality, the results of our investigation support the prognostic value of ECG regarding prognosis assessment following STEMI.

The results of our investigation basically support the data from the literature. Our study participants who presented with LVSD 6 months after STEMI, in comparison to those without LVSD, had significantly higher values of heart rate, number of leads with STsegment elevation and pathological Q-waves, sum of ST-segment elevation and maximal ST-segment elevation on admission to hospital and directly after PCI. They also showed a higher prevalence of anterior STEMI and considerably wider QRS after PCI, while QRS duration measurement at baseline showed no significant difference. Additionally, patients presenting with LVSD after 6 months showed more severe ischemia on admission, as assessed with Sclarovsky-Birnbaum ischemia score, smaller reciprocal ST-segment depression at baseline and less profound ST-segment resolution post PCI.

In univariate analysis, all but one of the ECG parameters predicted LVSD occurrence 6 months after STEMI, the most powerful being anterior location of STEMI (OR 17.44; 95\% CI 6.63-45.88). Our analysis also indicates good predictive value of ST-segment resolution and grade 3 according to the Sclarovsky-Birnbaum ischemia score, which came in as the second and third most powerful LVSD predictors. However, it is important to remember that some of the remaining parameters were reported per increments, which means that their actual final impact potentiates when the increments are multiplied in measurements. The only exception was QRS duration at baseline, which did not show statistical significance. In contrast to literature data, in our investigation, the presence of reciprocal ST-segment depressions diminished the likelihood of LVSD occurrence 6 months after STEMI. Whether this could be a consequence of shorter time-to-balloon delay in this group, compared with patients without reciprocal ST-segment depressions, remains a matter of speculation and requires verification in a larger group since the difference in time-to-balloon between patients with and without LVSD was not statistically significant.

In the model adjusted for demographic, clinical, biochemical and angiographic variables, however, the majority of the ECG parameters did not maintain statistical significance. The only two parameters contributing to the multivariate regression model and thus recognized as independent predictors of LVSD in 6-month follow-up were anterior location of STEMI (OR 17.78; 95\% CI 6.45-48.96; $p<0.001$ ) and post-PCI QRS duration (OR 1.56; 95\% CI 1.22-2.00; $p<0.001$ ) expressed per increment of $10 \mathrm{~ms}$. The highest tercile of post-PCI QRS duration (i.e., $\geq 100 \mathrm{~ms}$ ) was associated with the highest prevalence of LVSD after 6 months and therefore appears to have the best discriminative value. The highest terciles of baseline and post-PCI QRS duration were also associated with significantly lower values of LVEF, compared with lower terciles.

\subsection{Study Limitations}

There are some limitations of this study to be mentioned. First, the study population is a fraction of the original cohort of patients recruited between 2005 and 2008. The time that had elapsed from patient recruitment to the onset of the project and clinical practice modifications implemented over that time could possibly impact the results. Second, LVSD, used as the endpoint in our investigation, is a well-documented prognostic factor in postSTEMI patients; however, it is still a surrogate of clinical endpoints. The choice of LVSD as an endpoint was dictated by lack of power of this study to evaluate clinical endpoints. Third, the duration of follow-up in our research was restricted to 6 months. It seems likely that 
extending this period might render more favorable results in terms of predictive capabilities of ECG. Forth, the relatively moderate left ventricular systolic function impairment and the applied exclusion criteria noticeably blunting the risk of death and the rate of adverse cardiovascular outcomes in our study group, together with the relatively short time to reperfusion, limit the applicability of our results to all STEMI patients. This warrants further research in non-uniform STEMI cohorts before unrestricted extrapolation of our findings to the general population is feasible. Fifth, enhanced precision of evaluation of left ventricular systolic function, size of myocardial necrosis and patency of the coronary microcirculation could possibly be achieved by employing magnetic resonance imaging. Sixth, we routinely used neither fractional flow reserve measurement nor intravascular ultrasound for the assessment of non-culprit lesions. Seventh, non-critical, non-culprit coronary lesions (stenoses 70-90\%) were revascularized electively (within 1 month of the index hospital admission). This fact might have some impact on the study findings. Eighth, in a substantial number of our study participants, maximal concentration of cardiac troponin I exceeded $50 \mathrm{ng} / \mathrm{mL}$. These serum samples were not further diluted, preventing precise estimation of the biochemical infarct size. Ninth, patients with left bundle branch block, isolated posterior myocardial infarction, isolated right ventricular myocardial infarction or permanent atrial fibrillation were excluded from the study. Therefore, the study findings may not to be attributable to such patients. Finally, post-reperfusion ECG parameters in time points other than directly after PCI were not assessed.

\section{Conclusions}

According to our study, baseline and post-PCI ECG parameters possess a modest predictive value for LVSD occurrence within 6 months of a first STEMI.

Author Contributions: Conceptualization, M.K. (Marek Koziński) and J.K.; data curation, T.F.; formal analysis, M.K. (Michał Kasprzak); investigation, T.F.; methodology, T.F. and M.K. (Marek Koziński); project administration, J.K.; supervision, M.K. (Marek Koziński) and J.K.; visualization, M.K. (Michał Kasprzak); writing_original draft, T.F. and M.K. (Michał Kasprzak); writing—review and editing, M.K. All authors have read and agreed to the published version of the manuscript.

Funding: This study was supported by the financial resources of the Polish Ministry of Science and Higher Education for Science, 2008-2011 (Research Project No. N402179534).

Institutional Review Board Statement: The study was conducted according to the guidelines of the Declaration of Helsinki and approved by the Ethics Committee of Collegium Medicum, Nicolaus Copernicus University (protocol code KB 440/2004, date of approval 5 August 2004).

Informed Consent Statement: Informed consent was obtained from all subjects involved in the study.

Data Availability Statement: Data sharing is not applicable to this article.

Acknowledgments: We are grateful to the staff of the Echocardiography Laboratory, particularly Iwona Świątkiewicz, for performing echocardiographic examinations. We would also like to thank the residents and nurses for their important contribution in participant enrolment, blood sampling and data collection.

Conflicts of Interest: The authors declare that there is no conflict of interest. The funders had no role in the design of the study; in the collection, analyses, or interpretation of data; in the writing of the manuscript, or in the decision to publish the results.

\section{References}

1. Fye, W.B. A history of the origin, evolution, and impact of electrocardiography. Am. J. Cardiol. 1994, 73, 937-949. [CrossRef]

2. Herring, N.; Paterson, D.J. ECG diagnosis of acute ischaemia and infarction: Past, present and future. QJM 2006, 99, 219-230. [CrossRef] [PubMed]

3. Siha, H.; Das, D.; Fu, Y.; Zheng, Y.; Westerhout, C.M.; Storey, R.F.; James, S.; Wallentin, L.; Armstrong, P.W. Baseline Q waves as a prognostic modulator in patients with ST segment elevation: Insights from the PLATO trial. CMAJ 2012, 184, 1135-1142. [CrossRef] [PubMed] 
4. Kaul, P.; Fu, Y.; Westerhout, C.M.; Granger, C.B.; Armstrong, P.W. Relative prognostic value of baseline $Q$ wave and time from symptom onset among men and women with ST-elevation myocardial infarction undergoing percutaneous coronary intervention. Am. J. Cardiol. 2012, 110, 1555-1560. [CrossRef]

5. Weir, R.A.; McMurray, J.J. Epidemiology of heart failure and left ventricular dysfunction after acute myocardial infarction. Curr. Heart Fail. Rep. 2006, 3, 175-180. [CrossRef]

6. Sutton, M.G.; Sharpe, N. Left ventricular remodeling after myocardial infarction: Pathophysiology and therapy. Circulation 2000, 101, 2981-2988. [CrossRef]

7. Minicucci, M.F.; Azevedo, P.S.; Polegato, B.F.; Paiva, S.A.; Zornoff, L.A. Heart failure after myocardial infarction: Clinical implications and treatment. Clin. Cardiol. 2011, 34, 410-414. [CrossRef]

8. Cohn, J.N.; Ferrari, R.; Sharpe, N. Cardiac remodeling-Concepts and clinical implications: A consensus paper from an international forum on cardiac remodeling. Behalf of an International Forum on Cardiac Remodeling. J. Am. Coll. Cardiol. 2000, 35, 569-582. [CrossRef]

9. Weir, R.A.; McMurray, J.J.; Velazquez, E.J. Epidemiology of heart failure and left ventricular systolic dysfunction after acute myocardial infarction: Prevalence, clinical characteristics, and prognostic importance. Am. J. Cardiol. 2006, 97, 13F-25F. [CrossRef]

10. Velazquez, E.J.; Francis, G.S.; Armstrong, P.W.; Aylward, P.E.; Diaz, R.; O'Connor, C.M.; White, H.D.; Henis, M.; Rittenhouse, L.M.; Kilaru, R.; et al. An international perspective on heart failure and left ventricular systolic dysfunction complicating myocardial infarction: The VALIANT registry. Eur. Heart J. 2004, 25, 1911-1919. [CrossRef]

11. Świątkiewicz, I.; Magielski, P.; Woźnicki, M.; Gierach, J.; Jabłoński, M.; Fabiszak, T.; Koziński, M.; Sukiennik, A.; Bronisz, A.; Kubica, J. Occurrence and predictors of left ventricular systolic dysfunction at hospital discharge and in long-term follow-up after acute myocardial infarction treated with primary percutaneous coronary intervention. Kardiol. Pol. 2012, 70, 329-340. [PubMed]

12. Nicod, P.; Gilpin, E.; Dittrich, H.; Chappuis, F.; Ahnve, S.; Engler, R.; Henning, H.; Ross, J., Jr. Influence on prognosis and morbidity of left ventricular ejection fraction with and without signs of left ventricular failure after acute myocardial infarction. Am. J. Cardiol. 1988, 61, 1165-1171. [CrossRef]

13. Ottervanger, J.P.; Ramdat Misier, A.R.; Dambrink, J.H.; de Boer, M.J.; Hoorntje, J.C.; Gosselink, A.T.; Suryapranata, H.; Reiffers, S.; van 't Hof, A.W.J. Mortality in patients with left ventricular ejection fraction $\leq 30 \%$ after primary percutaneous coronary intervention for ST-elevation myocardial infarction. Am. J. Cardiol. 2007, 100, 793-797. [CrossRef] [PubMed]

14. Daneault, B.; Généreux, P.; Kirtane, A.J.; Witzenbichler, B.; Guagliumi, G.; Paradis, J.M.; Fahy, M.P.; Mehran, R.; Stone, G.W. Comparison of Three-year outcomes after primary percutaneous coronary intervention in patients with left ventricular ejection fraction $<40 \%$ versus $\geq 40 \%$ (from the HORIZONS-AMI trial). Am. J. Cardiol. 2013, 111, 12-20. [CrossRef] [PubMed]

15. Marenzi, G.; Moltrasio, M.; Assanelli, E.; Lauri, G.; Marana, I.; Grazi, M.; Rubino, M.; De Metrio, M.; Veglia, F.; Bartorelli, A.L. Impact of cardiac and renal dysfunction on inhospital morbidity and mortality of patients with acute myocardial infarction undergoing primary angioplasty. Am. Heart J. 2007, 153, 755-762. [CrossRef] [PubMed]

16. Murkofsky, R.L.; Dangas, G.; Diamond, J.A.; Mehta, D.; Schaffer, A.; Ambrose, J.A. A prolonged QRS duration on surface electrocardiogram is a specific indicator of left ventricular dysfunction. J. Am. Coll. Cardiol. 1998, 32, 476-482. [CrossRef]

17. Manes, C.; Pfeffer, M.A.; Rutherford, J.D.; Greaves, S.; Rouleau, J.L.; Arnold, J.M.; Menapace, F.; Solomon, S.D. Value of the electrocardiogram in predicting left ventricular enlargement and dysfunction after myocardial infarction. Am. J. Med. 2003, 114, 99-105. [CrossRef]

18. Kasprzak, M.; Fabiszak, T.; Koziński, M.; Kubica, J. Diagnostic Performance of Selected Baseline Electrocardiographic Parameters for Prediction of Left Ventricular Remodeling in Patients with ST-Segment Elevation Myocardial Infarction. J. Clin. Med. 2021, 10, 2405. [CrossRef] [PubMed]

19. Thygesen, K.; Alpert, J.S.; White, H.D. on behalf of the Joint ESC/ACCF/AHA/WHF Task Force for the Redefinition of Myocardial Infarction. Universal definition of myocardial infarction. Eur. Heart J. 2007, 28, 2525-2538.

20. Raymond, I.; Mehlsen, J.; Pedersen, F.; Dimsits, J.; Jacobsen, J.; Hildebrandt, P.R. The prognosis of impaired left ventricular systolic function and heart failure in a middle-aged and elderly population in an urban population segment of Copenhagen. Eur. J. Heart Fail. 2004, 6, 653-661. [CrossRef]

21. Krumholz, H.M.; Chen, J.; Chen, Y.T.; Wang, Y.; Radford, M.J. Predicting one-year mortality among elderly survivors of hospitalization for an acute myocardial infarction: Results from the Cooperative Cardiovascular Project. J. Am. Coll. Cardiol. 2001, 38, 453-459. [CrossRef]

22. Rott, D.; Behar, S.; Hod, H.; Feinberg, M.S.; Boyko, V.; Mandelzweig, L.; Kaplinsky, E.; Gottlieb, S.; Argatroban in Acute Myocardial Infarction-2 (ARGAMI-2) Study Group. Improved survival of patients with acute myocardial infarction with significant left ventricular dysfunction undergoing invasive coronary procedures. Am. Heart J. 2001, 141, 267-276. [CrossRef] [PubMed]

23. Swiatkiewicz, I.; Kozinski, M.; Magielski, P.; Gierach, J.; Fabiszak, T.; Kubica, A.; Sukiennik, A.; Navarese, E.P.; OdrowazSypniewska, G.; Kubica, J. Usefulness of C-reactive protein as a marker of early post-infarct left ventricular systolic dysfunction. Inflamm. Res. 2012, 61, 725-734. [CrossRef] [PubMed]

24. Møller, J.E.; Brendorp, B.; Ottesen, M.; Køber, L.; Egstrup, K.; Poulsen, S.H.; Torp-Pedersen, C. Congestive heart failure with preserved left ventricular systolic function after acute myocardial infarction: Clinical and prognostic implications. Eur. J. Heart Fail. 2003, 5, 811-819. [CrossRef] 
25. McDonagh, T.A.; Metra, M.; Adamo, M.; Gardner, R.S.; Baumbach, A.; Böhm, M.; Burri, H.; Butler, J.; Čelutkienè, J.; Chioncel, O.; et al. 2021 ESC Guidelines for the diagnosis and treatment of acute and chronic heart failure. Eur Heart J. 2021, 42, $3599-3726$. [CrossRef]

26. Ibanez, B.; James, S.; Agewall, S.; Antunes, M.J.; Bucciarelli-Ducci, C.; Bueno, H.; Caforio, A.L.P.; Crea, F.; Goudevenos, J.A.; Halvorsen, S.; et al. 2017 ESC Guidelines for the management of acute myocardial infarction in patients presenting with STsegment elevation: The Task Force for the management of acute myocardial infarction in patients presenting with ST-segment elevation of the European Society of Cardiology (ESC). Eur. Heart J. 2018, 39, 119-177.

27. Lang, R.; Bierig, M.; Devereux, B.; Flachskampf, F.A.; Foster, E.; Pellikka, P.A.; Picard, M.H.; Roman, M.J.; Seward, J.; Shanewise, J.; et al. Recommendations for chamber quantification. Eur. J. Echocardiogr. 2006, 7, 79-108. [CrossRef]

28. Schiller, N.; Shah, P.; Crawford, M.; DeMaria, A.; Devereux, R.; Feigenbaum, H.; Gutgesell, H.; Reichek, N.; Sahn, D.; Schnittger, I.; et al. Recommendations for quantitation of the left ventricle by two-dimensional echocardiography. J. Am. Soc. Echocardiogr. 1989, 2, 358-367. [CrossRef]

29. Kannel, W.B. Risk stratification in hypertension: New insights from the Framingham Study. Am. J. Hypertens. 2000, 13, 3S-10S. [CrossRef]

30. Hori, M.; Okamoto, H. Heart rate as a target of treatment of chronic heart failure. J. Cardiol. 2012, 60, 86-90. [CrossRef]

31. Perret-Guillaume, C.; Joly, L.; Benetos, A. Heart rate as a risk factor for cardiovascular disease. Prog. Cardiovasc. Dis. 2009, 52, 6-10. [CrossRef] [PubMed]

32. Palatini, P.; Thijs, L.; Staessen, J.A.; Fagard, R.H.; Bulpitt, C.J.; Clement, D.L.; de Leeuw, P.W.; Jaaskivi, M.; Leonetti, G.; Nachev, C.; et al. Predictive value of clinic and ambulatory heart rate for mortality in elderly subjects with systolic hypertension. Arch. Intern. Med. 2002, 162, 2313-2321. [CrossRef] [PubMed]

33. Reunanen, A.; Karjalainen, J.; Ristola, P.; Heliövaara, M.; Knekt, P.; Aromaa, A. Heart rate and mortality. J. Intern. Med. 2000, 247, 231-239. [CrossRef]

34. Jensen, M.T.; Marott, J.L.; Allin, K.H.; Nordestgaard, B.G.; Jensen, G.B. Resting heart rate is associated with cardiovascular and all-cause mortality after adjusting for inflammatory markers: The Copenhagen City Heart Study. Eur. J. Prev. Cardiol. 2012, 19, 102-108. [CrossRef]

35. Jouven, X.; Empana, J.P.; Schwartz, P.J.; Desnos, M.; Courbon, D.; Ducimetière, P. Heart-rate profile during exercise as a predictor of sudden death. N. Engl. J. Med. 2005, 352, 1951-1958. [CrossRef] [PubMed]

36. Diaz, A.; Bourassa, M.G.; Guertin, M.C.; Tardif, J.C. Long-term prognostic value of resting heart rate in patients with suspected or proven coronary artery disease. Eur. Heart J. 2005, 26, 967-974. [CrossRef] [PubMed]

37. Shaper, A.G.; Wannamethee, G.; Macfarlane, P.W.; Walker, M. Heart rate, ischaemic heart disease, and sudden cardiac death in middle-aged British men. Br. Heart J. 1993, 70, 49-55. [CrossRef]

38. Kolloch, R.; Legler, U.F.; Champion, A.; Cooper-Dehoff, R.M.; Handberg, E.; Zhou, Q.; Pepine, C.J. Impact of resting heart rate on outcomes in hypertensive patients with coronary artery disease: Findings from the INternationalVErapamil-SR/trandolapril STudy (INVEST). Eur. Heart J. 2008, 29, 1327-1334. [CrossRef]

39. O'Riordan, M. High Heart Rate Linked with Increased Mortality in Stable Coronary Heart Disease. Medscape 2010. Available online: http:/ / www.medscape.com/viewarticle/731449 (accessed on 14 October 2021).

40. Lonn, E.M.; Rambihar, S.; Gao, P.; Custodis, F.F.; Sliwa, K.; Teo, K.K.; Yusuf, S.; Böhm, M. Heart rate is associated with increased risk of major cardiovascular events, cardiovascular and all-cause death in patients with stable chronic cardiovascular disease: An analysis of ONTARGET/TRANSCEND. Clin. Res. Cardiol. 2014, 103, 149-159. [CrossRef]

41. MERIT-HF Study Group. Effect of metoprolol CR/XL in chronic heart failure: Metoprolol CR/XL Randomised Intervention Trial in Congestive Heart Failure (MERIT-HF). Lancet 1999, 353, 2001-2007. [CrossRef]

42. Gullestad, L.; Wikstrand, J.; Deedwania, P.; Hjalmarson, A.; Egstrup, K.; Elkayam, U.; Gottlieb, S.; Rashkow, A.; Wedel, H.; Bermann, G.; et al. What resting heart rate should one aim for when treating patients with heart failure with a beta-blocker? Experiences from the Metoprolol Controlled Release/Extended Release Randomized Intervention Trial in Chronic Heart Failure (MERIT-HF). J. Am. Coll. Cardiol. 2005, 45, 252-259. [CrossRef] [PubMed]

43. Lechat, P.; Hulot, J.S.; Escolano, S.; Mallet, A.; Leizorovicz, A.; Werhlen-Grandjean, M.; Pochmalicki, G.; Dargie, H. Heart rate and cardiac rhythm relationships with bisoprolol benefit in chronic heart failure in CIBIS II Trial. Circulation 2001, 103, 1428-1433. [CrossRef] [PubMed]

44. Böhm, M.; Swedberg, K.; Komajda, M.; Borer, J.S.; Ford, I.; Dubost-Brama, A.; Dubost-Brama, A.; Lerebours, G.; Tavazzi, L. Heart rate as a risk factor in chronic heart failure (SHIFT): The association between heart rate and outcomes in a randomised placebo-controlled trial. Lancet 2010, 376, 886-894. [CrossRef]

45. Swedberg, K.; Komajda, M.; Böhm, M.; Borer, J.S.; Ford, I.; Dubost-Brama, A.; Lerebours, G.; Tavazzi, L. Ivabradine and outcomes in chronic heart failure (SHIFT): A randomised placebo-controlled study. Lancet 2010, 376, 875-885. [CrossRef]

46. Berton, G.S.; Cordiano, R.; Palmieri, R.; Gheno, G.; Mormino, P.; Palatini, P. Heart rate during myocardial infarction: Relationship with one-year global mortality in men and women. Can. J. Cardiol. 2002, 18, 495-502. [PubMed]

47. Hjalmarson, A.; Gilpin, E.A.; Kjekshus, J.; Schieman, G.; Nicod, P.; Henning, H.; Ross, J., Jr. Influence of heart rate on mortality after acute myocardial infarction. Am. J. Cardiol. 1990, 65, 547-553. [CrossRef]

48. Zuanetti, G.; Hernandez-Bernal, F.; Rossi, A.; Comerio, G.; Paolucci, G.; Maggioni, A.P. Relevance of heart rate as a prognostic factor in patients with acute myocardial infarction: The GISSI experience. Eur. Heart J. 1999, 1, H52-H57. 
49. Antoni, M.L.; Boden, H.; Delgado, V.; Boersma, E.; Fox, K.; Schalij, M.J.; Bax, J.J. Relationship between discharge heart rate and mortality in patients after acute myocardial infarction treated with primary percutaneous coronary intervention. Eur. Heart $J$. 2012, 33, 96-102. [CrossRef]

50. Hathaway, W.R.; Peterson, E.D.; Wagner, G.S.; Granger, C.B.; Zabel, K.M.; Pieper, K.S.; Clark, K.A.; Woodlief, L.H.; Califf, R.M. Prognostic significance of the initial electrocardiogram in patients with acute myocardial infarction. GUSTO-I Investigators. Global Utilization of Streptokinase and t-PA for Occluded Coronary Arteries. JAMA 1998, 279, 387-391. [CrossRef]

51. Harjai, K.J.; Mehta, R.H.; Stone, G.W.; Boura, J.A.; Grines, L.; Brodie, B.R.; Cox, D.A.; O'Neill, W.W.; Grines, C.L. Does proximal location of culprit lesion confer worse prognosis in patients undergoing primary percutaneous coronary intervention for ST elevation myocardial infarction? J. Interv. Cardiol. 2006, 19, 285-294. [CrossRef]

52. Conde-Vela, C.; Moreno, R.; Hernández, R.; Pérez-Vizcayno, M.J.; Alfonso, F.; Escaned, J.; Sabaté, M.; Bañuelos, C.; Macaya, C. Cardiogenic shock at admission in patients with multivessel disease and acute myocardial infarction treated with percutaneous coronary intervention: Related factors. Int. J. Cardiol. 2007, 123, 29-33. [CrossRef]

53. Jarai, R.; Huber, K.; Bogaerts, K.; Sinnaeve, P.R.; Ezekowitz, J.; Ross, A.M.; Zeymer, U.; Armstrong, P.W.; Van de Werf, F.J Prediction of cardiogenic shock using plasma B-type natriuretic peptide and the N-terminal fragment of its pro-hormone [corrected] concentrations in ST elevation myocardial infarction: An analysis from the ASSENT-4 Percutaneous Coronary Intervention Trial. Crit. Care Med. 2010, 38, 1793-1801. [CrossRef] [PubMed]

54. Bolognese, L.; Neskovic, A.N.; Parodi, G.; Cerisano, G.; Buonamici, P.; Santoro, G.M.; Antoniucci, D. Left ventricular remodeling after primary coronary angioplasty: Patterns of left ventricular dilation and long-term prognostic implications. Circulation 2002, 106, 2351-2357. [CrossRef] [PubMed]

55. Mattichak, S.J.; Harjai, K.J.; Dutcher, J.R.; Boura, J.A.; Stone, G.; Cox, D.; Brodie, B.R.; O'Neill, W.W.; Grines, C.L. Left ventricular remodeling and systolic deterioration in acute myocardial infarction: Findings from the Stent-PAMI Study. J. Interv. Cardiol. 2005, 18, 255-260. [CrossRef]

56. Rodríguez-Palomares, J.F.; Figueras-Bellot, J.; Descalzo, M.; Moral, S.; Otaegui, I.; Pineda, V.; Del Blanco, B.G.; González-Alujas, M.T.; Evangelista Masip, A.; García-Dorado, D. Relation of ST-segment elevation before and after percutaneous transluminal coronary angioplasty to left ventricular area at risk, myocardial infarct size, and systolic function. Am. J. Cardiol. 2014, 113, 593-600. [CrossRef] [PubMed]

57. Mauri, F.; Franzosi, M.G.; Maggioni, A.P.; Santoro, E.; Santoro, L. Clinical value of 12-lead electrocardiography to predict the long-term prognosis of GISSI-1 patients. J. Am. Coll. Cardiol. 2002, 39, 1594-1600. [CrossRef]

58. Sejersten, M.; Ripa, R.S.; Maynard, C.; Wagner, G.S.; Andersen, H.R.; Grande, P.; Mortensen, L.S.; Clemmensen, P. Usefulness of quantitative baseline ST-segment elevation for predicting outcomes after primary coronary angioplasty or fibrinolysis (results from the DANAMI-2 trial). Am. J. Cardiol. 2006, 97, 611-616. [CrossRef]

59. Husser, O.; Bodí, V.; Sanchis, J.; Núnez, J.; Mainar, L.; Rumiz, E.; López-Lereu, M.P.; Monmeneu, J.; Chaustre, F.; Trapero, I.; et al. The sum of ST-segment elevation is the best predictor of microvascular obstruction in patients treated successfully by primary percutaneous coronary intervention. Cardiovascular magnetic resonance study. Rev. Esp. Cardiol. 2010, 63, 1145-1154. [CrossRef]

60. Bigi, R.; Mafrici, A.; Colombo, P.; Gregori, D.; Corrada, E.; Alberti, A.; De Biase, A.; Orrego, P.S.; Fiorentini, C.; Klugmann, S. Relation of terminal QRS distortion to left ventricular functional recovery and remodeling in acute myocardial infarction treated with primary angioplasty. Am. J. Cardiol. 2005, 96, 1233-1236. [CrossRef]

61. Van der Zwaan, H.B.; Stoel, M.G.; Roos-Hesselink, J.W.; Veen, G.; Boersma, E.; von Birgelen, C. Early versus late ST-segment resolution and clinical outcomes after percutaneous coronary intervention for acute myocardial infarction. Neth. Heart J. 2010, 18, 416-422. [CrossRef]

62. Farkouh, M.E.; Reiffel, J.; Dressler, O.; Nikolsky, E.; Parise, H.; Cristea, E.; Baran, D.A.; Dizon, J.; Merab, J.P.; Lansky, A.J.; et al. Relationship between ST-segment recovery and clinical outcomes after primary percutaneous coronary intervention: The HORIZONSAMI ECG substudy report. Circ. Cardiovasc. Interv. 2013, 6, 216-223. [CrossRef] [PubMed]

63. Vaturi, M.; Birnbaum, Y. The use of the electrocardiogram to identify epicardial coronary and tissue reperfusion in acute myocardial infarction. J. Thromb. Thrombolysis 2000, 10, 137-147. [CrossRef] [PubMed]

64. Kumar, S.; Sivagangabalan, G.; Hsieh, C.; Ryding, A.D.; Narayan, A.; Chan, H.; Burgess, D.C.; Ong, A.T.; Sadick, N.; Kovoor, P. Predictive value of ST resolution analysis performed immediately versus at ninety minutes after primary percutaneous coronary intervention. Am. J. Cardiol. 2010, 105, 467-474. [CrossRef] [PubMed]

65. Matetzky, S.; Novikov, M.; Gruberg, L.; Freimark, D.; Feinberg, M.; Elian, D.; Novikov, I.; Di Segni, E.; Agranat, O.; Har-Zahav, Y.; et al. The significance of persistent ST elevation versus early resolution of ST segment elevation after primary PTCA. J. Am. Coll. Cardiol. 1999, 34, 1932-1938. [CrossRef]

66. Buller, C.E.; Fu, Y.; Mahaffey, K.W.; Todaro, T.G.; Adams, P.; Westerhout, C.M.; White, H.D.; van 't Hof, A.W.; Van de Werf, F.J.; Wagner, G.S.; et al. ST-segment recovery and outcome after primary percutaneous coronary intervention for ST-elevation myocardial infarction: Insights from the Assessment of Pexelizumab in Acute Myocardial Infarction (APEX-AMI) trial. Circulation 2008, 118, 1335-1346. [CrossRef]

67. Wolak, A.; Yaroslavtsev, S.; Amit, G.; Birnbaum, Y.; Cafri, C.; Atar, S.; Gilutz, H.; Ilia, R.; Zahger, D. Grade 3 ischemia on the admission electrocardiogram predicts failure of ST resolution and of adequate flow restoration after primary percutaneous coronary intervention for acute myocardial infarction. Am. Heart J. 2007, 153, 410-417. [CrossRef] [PubMed] 
68. Schröder, R.; Wegscheider, K.; Schröder, K.; Dissmann, R.; Meyer-Sabellek, W. Extent of early ST segment elevation resolution: A strong predictor of outcome in patients with acute myocardial infarction and a sensitive measure to compare thrombolytic regimens. A substudy of the International Joint Efficacy Comparison of Thrombolytics (INJECT) trial. J. Am. Coll. Cardiol. 1995, 26, 1657-1664. [PubMed]

69. Peterson, E.D.; Hathaway, W.R.; Zabel, K.M.; Pieper, K.S.; Granger, C.B.; Wagner, G.S.; Topol, E.J.; Bates, E.R.; Simoons, M.L.; Califf, R.M. Prognostic significance of precordial ST segment depression during inferior myocardial infarction in the thrombolytic era: Results in 16,521 patients. J. Am. Coll. Cardiol. 1996, 28, 305-312. [CrossRef]

70. Birnbaum, Y.; Herz, I.; Sclarovsky, S.; Zlotikamien, B.; Chetrit, A.; Olmer, L.; Barbash, G.I. Prognostic significance of precordial ST segment depression on admission electrocardiogram in patients with inferior wall myocardial infarction. J. Am. Coll. Cardiol. 1996, 28, 313-318. [CrossRef]

71. Kozuch, M.; Dobrzycki, S.; Nowak, K.; Prokopczuk, P.; Kralisz, P.; Bachorzewska-Gajewska, H.; Kaminski, K.; Kozieradzka, A.; Korecki, J.; Poniatowski, B.; et al. Lack of ST-segment depression normalization after PCI is a predictor of 5-year mortality in patients with ST-elevation myocardial infarction. Circ. J. 2007, 71, 1851-1856. [CrossRef] [PubMed]

72. Armstrong, P.W.; Fu, Y.; Westerhout, C.M.; Hudson, M.P.; Mahaffey, K.W.; White, H.D.; Todaro, T.G.; Adams, P.X.; Aylward, P.E.; Granger, C.B. Baseline Q-wave surpasses time from symptom onset as a prognostic marker in ST-segment elevation myocardial infarction patients treated with primary percutaneous coronary intervention. J. Am. Coll. Cardiol. 2009, 53, 1503-1509. [CrossRef]

73. López-Castillo, M.; Aceña, Á.; Pello-Lázaro, A.M.; Viegas, V.; Merchán Muñoz, B.; Carda, R.; Franco-Peláez, J.; Martín-Mariscal M.L.; Briongos-Figuero, S.; Tuñón, J. Prognostic value of initial QRS analysis in anterior STEMI: Correlation with left ventricular systolic dysfunction, serum biomarkers, and cardiac outcomes. Ann. Noninvasive Electrocardiol. 2021, 26, e12791. [CrossRef]

74. Birnbaum, Y.; Sclarovsky, S. The grades of ischemia on the presenting electrocardiogram of patients with ST elevation acute myocardial infarction. J. Electrocardiol. 2001, 34, 17-26. [CrossRef] [PubMed]

75. Garcia-Rubira, J.C.; Perez-Leal, I.; Garcia-Martinez, J.T.; Molano, F.; Hidalgo, R.; Gómez-Barrado, J.J.; Cruz, J.M. The initial electrocardiographic pattern is a strong predictor of outcome in acute myocardial infarction. Int. J. Cardiol. 1995, 51, 301-305. [CrossRef]

76. Birnbaum, Y.; Herz, I.; Sclarovsky, S.; Zlotikamien, B.; Chetrit, A.; Olmer, L.; Barbash, G.I. Admission clinical and electrocardiographic characteristics predicting an increased risk for early reinfarction after thrombolytic therapy. Am. Heart J. 1998, 135, 805-812. [CrossRef]

77. Birnbaum, Y.; Herz, I.; Sclarovsky, S.; Zlotikamien, B.; Chetrit, A.; Olmer, L.; Barbash, G.I. Prognostic significance of the admission electrocardiogram in acute myocardial infarction. J. Am. Coll. Cardiol. 1996, 27, 1128-1132. [CrossRef]

78. Birnbaum, Y.; Goodman, S.; Barr, A.; Gates, K.B.; Barbash, G.I.; Battler, A.; Barbagelata, A.; Clemmensen, P.; Sgarbossa, E.B.; Granger, C.B.; et al. Comparison of primary coronary angioplasty versus thrombolysis in patients with ST-segment elevation acute myocardial infarction and grade II and grade III myocardial ischemia on the enrollment electrocardiogram. Am. J. Cardiol. 2001, 88, 842-847. [CrossRef]

79. Birnbaum, Y.; Kloner, R.; Sclarovsky, S.; Cannon, C.P.; McCabe, C.H.; Davis, V.G.; Zaret, B.L.; Wackers, F.J.; Braunwald, E. Distortion of the terminal portion of the QRS on the admission electrocardiogram in acute myocardial infarction and correlation with infarct size and long term prognosis (Thrombolysis in Myocardial Infarction 4 Trial). Am. J. Cardiol. 1996, 78, 396-403. [CrossRef]

80. Birnbaum, Y.; Maynard, C.; Wolfe, S.; Mager, A.; Strasberg, B.; Rechavia, E.; Gates, K.; Wagner, G.S. Terminal QRS distortion on admission is better than ST-segment measurements in predicting final infarct size and assessing the Potential effect of thrombolytic therapy in anterior wall acute myocardial infarction. Am. J. Cardiol. 1999, 84, 530-534. [CrossRef]

81. Birnbaum, Y.; Criger, D.A.; Wagner, G.S.; Strasberg, B.; Mager, A.; Gates, K.; Granger, C.B.; Ross, A.M.; Barbash, G.I. Prediction of the extent and severity of left ventricular dysfunction in anterior acute myocardial infarction by the admission electrocardiogram. Am. Heart J. 2001, 141, 915-924. [CrossRef] [PubMed]

82. Lee, C.W.; Hong, M.K.; Yang, H.S.; Choi, S.W.; Kim, J.J.; Park, S.W.; Park, S.J. Determinants and prognostic implications of terminal QRS complex distortion in patients treated with primary angioplasty for acute myocardial infarction. Am. J. Cardiol. 2001, 88, 210-213. [CrossRef]

83. Valle-Caballero, M.J.; Fernández-Jiménez, R.; Díaz-Munoz, R.; Mateos, A.; Rodríguez-Álvarez, M.; Iglesias-Vázquez, J.A.; Saborido, C.; Navarro, C.; Dominguez, M.L.; Gorjón, L.; et al. QRS distortion in pre-reperfusion electrocardiogram is a bedside predictor of large myocardium at risk and infarct size (a METOCARD-CNIC trial substudy). Int. J. Cardiol. 2016, 202, 666-673. [CrossRef] [PubMed]

84. Fernandez-Jimenez, R.; Valle-Caballero, M.J.; Diaz-Munoz, R.; Pizarro, G.; Fernandez-Friera, L.; Garcia-Ruiz, J.M.; Garcia-Alvarez, A.; Fuster, V.; Garcia-Rubira, J.C.; Ibanez, B. Terminal QRS distortion is an independent predictor of large area at risk and infarct size in patients with anterior STEMI. J. Am. Coll. Cardiol. 2015, 65, A196. [CrossRef]

85. Tamura, A.; Nagase, K.; Watanabe, T.; Nasu, M. Relationship between terminal QRS distortion on the admission and the time course of left ventricular wall motion in anterior wall acute myocardial infarction. Jpn. Circ. J. 2001, 65, 63-66. [CrossRef]

86. Iuliano, S.; Fisher, S.G.; Karasik, P.E.; Fletcher, R.D.; Singh, S.N. QRS duration and mortality in patients with congestive heart failure. Am. Heart J. 2002, 143, 1085-1091. [CrossRef] [PubMed] 
87. Oikarinen, L.; Nieminen, M.S.; Viitasalo, M.; Toivonen, L.; Sverker, J.; Dahlöf, B.; Devereux, R.B.; Okin, P.M. QRS Duration and QT Interval Predict Mortality in Hypertensive Patients With Left Ventricular Hypertrophy. The Losartan Intervention for Endpoint Reduction in Hypertension Study. Hypertension 2004, 43, 1029-1034. [CrossRef] [PubMed]

88. Bauer, A.; Watanabe, M.A.; Barthel, P.; Schneider, R.; Ulm, K.; Schmidt, G. QRS duration and late mortality in unselected post-infarction patients of the revascularization era. Eur. Heart J. 2006, 27, 427-433. [CrossRef] [PubMed]

89. Nwakile, C.; Purushottam, B.; Yun, J.; Bhalla, V.; Morris, D.L.; Figueredo, V.M. QRS duration predicts 30 day mortality following ST elevation myocardial infarction. Int. J. Cardiol. Heart Vasc. 2014, 5, 42-44. [PubMed]

90. Olesen, L.L.; Andersen, A. ECG as a first step in the detection of left ventricular systolic dysfunction in the elderly. ESC Heart Fail. 2016, 3, 44-52. [CrossRef] 